\title{
A new Middle Pleistocene interglacial occurrence from Ejby, Sjælland, Denmark
}

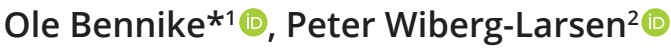 \\ ${ }^{1}$ Geological Survey of Denmark and Greenland (GEUS), Aarhus, Denmark; 'Institute for Ecoscience, Aarhus University, Silkeborg, Denmark.
}

\begin{abstract}
Despite more than a century of investigations, parts of the Quaternary stratigraphy of Denmark with their fragmented record of deposits remain ambiguous. Here we describe a newly found interglacial clay deposit from Ejby on Sjælland, Denmark, from a borehole at $55.695^{\circ} \mathrm{N}, 11.839^{\circ} \mathrm{E}$ (terrain elevation $5.7 \mathrm{~m}$ above sea level). We place the new occurrence on record and provide details of the macrofossil analysis of the sample. The clay contains remains of the present-day temperate bivalve Corbicula fluminalis and the caddis fly Hydropsyche contubernalis - both inhabiting rivers. The presence of C. fluminalis indicates that the deposit most probably is of Middle Pleistocene age, older than the last interglacial, the Eemian.
\end{abstract}

\section{Introduction}

During the Quaternary period that began 2.58 million years, the climate has alternated between glacial and interglacial conditions. Interglacial deposits are characterised by remains of plants and animals such as oak and red deer that indicate climatic conditions similar to or warmer than at present, whereas interstadial deposits from glacial stages contain remains of relatively cold-adapted, Arctic or subarctic species such as polar willow and reindeer. Despite more than a century of investigations, parts of the Quaternary stratigraphy of Denmark with their fragmented record of deposits remain ambiguous. Known interglacial occurrences include the Cromerian complex (the Harreskovian, marine isotope stage [MIS] 19), the Holsteinian (MIS 11C), the Trelde Klint interglacial (MIS 11), the Trianglen interglacial (MIS 7), the Eemian (MIS 5e) and the current interglacial, the Holocene (Kuneš et al. 2013; Odgaard et al. 2016; Bennike et al. 2019; Candy et al. 2021). Moreover, several deposits of unknown age have been described (Andersen 1967).

In 2018, the Geological Survey of Denmark and Greenland (GEUS) received samples collected at 3-m intervals from a borehole at $55.695^{\circ} \mathrm{N}, 11.839^{\circ} \mathrm{E}$ (terrain elevation $5.7 \mathrm{~m}$ a.s.l.), at the address Ejby Havnevej 101 on Sjælland (Fig. 1). Shells of the bivalve Corbicula were noted in one of the samples; this species indicates a Middle Pleistocene interglacial age (Meijer \& Preece 2000; Bennike et al. 2019), and since such occurrences are rare in Denmark, we decided to conduct analyses of macrofossils. This data article puts the new occurrence on record and provides details of the macrofossil analysis of the sample. The identification of fossils from a deposit can help us determine

\author{
*Correspondence: obe@geus.dk \\ Received: 08 Sept 2021 \\ Accepted: 03 Jan 2022 \\ Published: 02 Mar 2022 \\ Keywords: Middle Pleistocene, \\ Quaternary, interglacial, river \\ macroinvertebrates, Denmark
}

\begin{abstract}
Abbreviations:
GEUS: Geological Survey of Denmark and Greenland

MIS: Marine Isotope Stage

cal. years BP: calendar years before present

a.s.l.: above sea level

b.s.l.: below sea level

GEUS Bulletin is an open access, peer-reviewed journal published by the Geological Survey of Denmark and Greenland (GEUS). This article is distributed under a CC-BY 4.0 licence, permitting free redistribution, and reproduction for any purpose, even commercial, provided proper citation of the original work. Author(s) retain copyright.
\end{abstract}

Edited by: Sofie Lindström, GEUS, Denmark

Reviewed by: Anne Elisabeth Bjune (University of Bergen, Norway), Matthew Pound (Northumbria University, UK).

Funding: None provided

Competing interests: See page 4

Additional files: See page 4 
the age and palaeoenvironment of the deposit. We also briefly review other interglacial and interstadial occurrences from eastern Denmark.

\section{Lithostratigraphy}

The drilling penetrated clayey till, glaciofluvial gravel, clay with bivalve shells, glaciofluvial gravel and Danian limestone (Fig. 2). Drilling stopped at a depth of $147.5 \mathrm{~m}$ below the terrain surface.

\section{Materials and methods}

Only a single sediment sample was available for analysis of macrofossils from the clay unit with bivalve shells. The sample weighed c. 200 g. It was soaked in a $\mathrm{NaOH}$ solution at room temperature for 2 days and wet sieved on $0.4-, 0.2$ - and $0.1-\mathrm{mm}$ sieves. The residue left on the sieves was analysed using a dissecting microscope.

\section{Results and discussion}

The results of the macrofossil analyses are presented in Table 1. The sample was small, and we only found the remains of five taxa. However, some of them are of interest, providing insights into the age and palaeoenvironmental conditions.

Vascular plants are represented by two taxa. Betula sect. Albae sp. (tree birch) is common in interglacial assemblages. The small birch nutlets are produced in vast quantities and easily dispersed by wind or rivers. The presence of tree birch indicates a forested environment. Zannichellia palustris (horned pondweed) is a small, submerged, perennial water plant that grows in shallow, fresh or brackish waters, in lakes and rivers. It has a wide geographical range, but it does not grow in

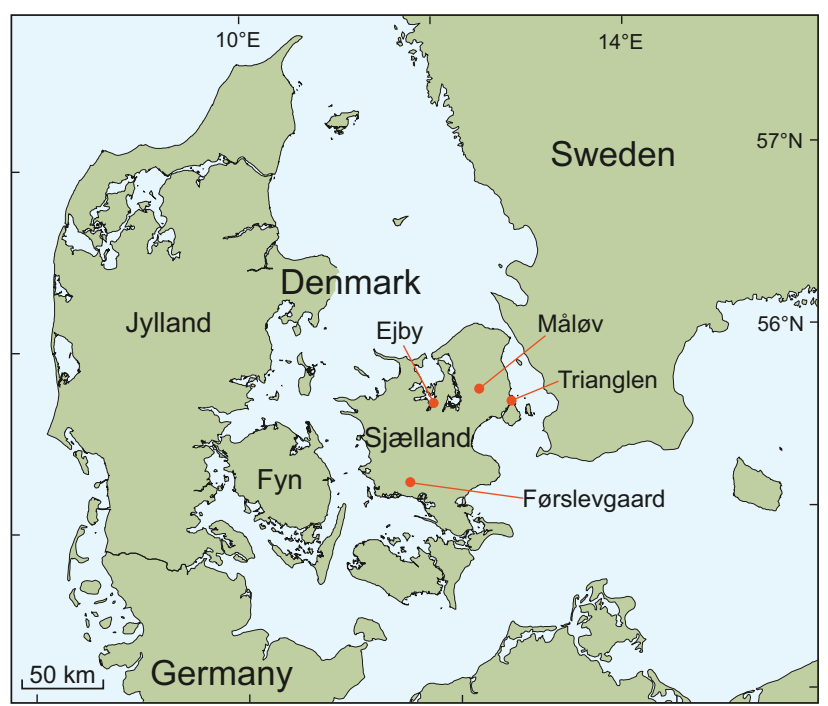

Fig. 1 Map of Denmark showing the location of Ejby and other Middle Pleistocene interglacial deposits on Sjælland discussed in the text.
Arctic regions. Achenes of Z. palustris have previously been reported from interglacial deposits in Denmark by Hartz (1909) and Bennike et al. (2019).

Invertebrates are represented by shells of the bivalve Corbicula fluminalis (Fig. 3). The Pleistocene occurrence of this species was discussed by Meijer \& Preece (2000), who concluded that the species was present only in temperate stages. Although mainly a fresh-water species that lives in rivers, it may have been able to tolerate slightly brackish conditions. It occurred in north-western Europe during the Early and Middle Pleistocene, whereas it was absent during the Last Interglacial. In Denmark, it has been found in interglacial deposits from the former Free Port in Copenhagen Johansen 1904), a deposit nowadays referred to MIS 7 (Bennike et al. 2019). The species has also been reported from an interglacial deposit at Førslevgaard in southern Sjælland (Johansen 1904; location in Fig. 1). The age of the deposit at Førslevgaard is unknown, but its fauna indicates a Middle Pleistocene age.

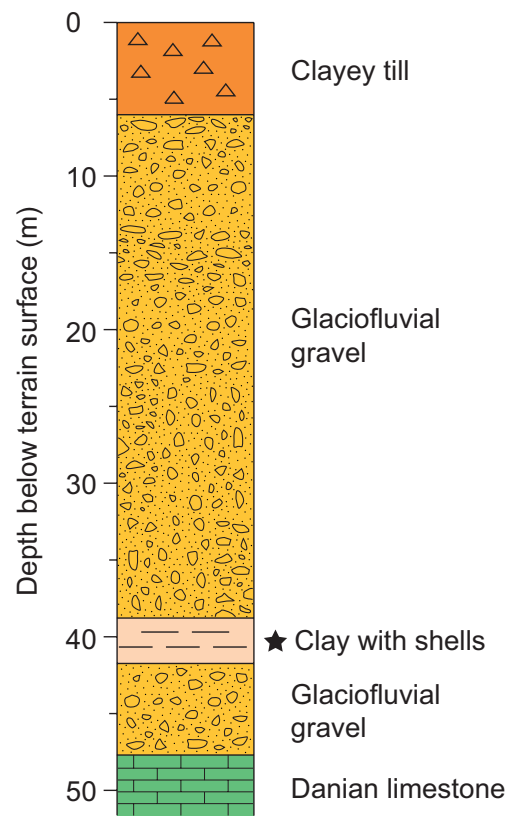

Fig. 2 Lithological log of the well from Ejby (DGU no. 198.964). Samples were collected at an interval of $3 \mathrm{~m}$, and the exact thicknesses of the units are unknown. Drilling stopped at a depth of $147.5 \mathrm{~m}$ below the terrain surface. The star shows the position of the analysed sample. More details on the sediments can be found at https://data.geus.dk/JupiterWWW/borerapport. jsp?borid=599264.

Table 1 Macrofossils from the interglacial deposit at Ejby, Sjælland.

Plants

Betula sect. Albae (nutlet)

1

Zannichellia palustris (achene)

1

Invertebrates

Daphnia cf. pulex (ephippium)

Hydropsyche contubernalis (frontoclypeal apotomes)

Corbicula fluminalis (shells)
1

10 


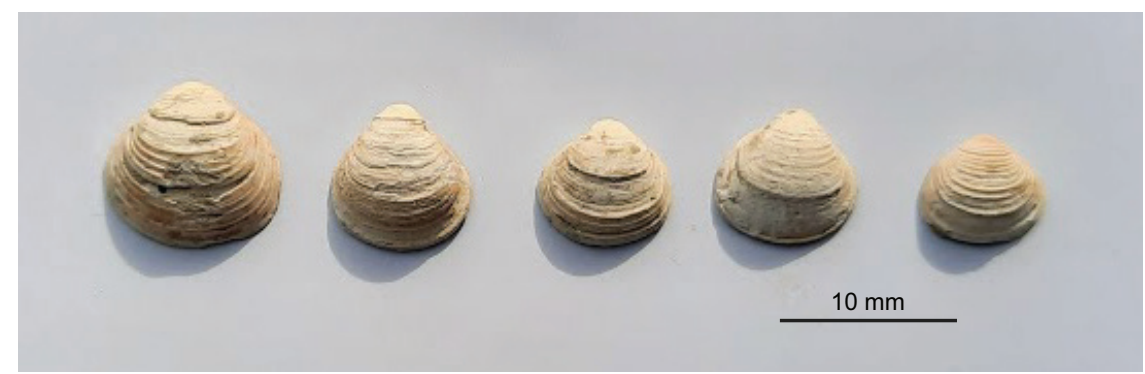

Fig. 3 Five shells of Corbicula fluminalis from Ejby.

In addition to bivalve shells, two frontoclypeal apotomes of larvae of the caddisfly (Trichoptera) Hydropsyche contubernalis were found. Like C. fluminalis, H. contubernalis is mainly a fluvial species, nowadays living primarily on the stony or coarse gravel bottom of rivers. However, it is also found in stony, wind-exposed, littoral zones of large lakes, especially in the northern parts of Europe (Rinne \& Wiberg-Larsen 2017). H. contubernalis nowadays occurs in Arresø, the largest lake in Denmark (Wiberg-Larsen 2010). On the undersurface of the substrates mentioned above, larvae build retreats of mineral and organic coarse particles, and in association with these, they spin silky capture nets. The nets function as traps for micro- and macroinvertebrate prey, transported downstream by the flowing water (or by turbulent currents in lakes). H. contubernalis is nowadays widely distributed throughout Europe, from northern Scandinavia to Spain and the Balkans, extending to the British Isles in the west and in the east to the Urals (Neu et al. 2018). There are Quaternary Danish records from c. 13300 cal. years BP (Coope \& Böcher 2000) and 10400 cal. years BP (Wiberg-Larsen et al. 2001), respectively. In the United Kingdom, remains of the species are recorded from Late Pleistocene deposits (age 35 000-60 000 years BP); Langford et al. 2014), and Horton et al. (1992) found remains of this and two other hydropsychids in fluvial deposits suggested to be of Hoxnian stage II age. According to Ashton et al. (2008), this may correspond to the Middle Pleistocene, MIS 11, corresponding to c. 420 000-370 000 years BP.

Finally, a single ephippium of Daphnia was found. The ephippium is similar to ephippia produced by $D$. pulex, but it could also represent other species in the Daphnia genus. Daphnia is a small planktonic crustacean that is often abundant in lakes and ponds, but it can also live in slow-flowing or stagnant parts of rivers.
Analyses of mitochondrial sequence data (e.g. COI and 165 genes) of aquatic and terrestrial organisms have revealed that the Pleistocene was an important period for generating biodiversity, also of species that still exist (e.g. Hungerer \& Kadereit 1998; Ribera \& Vogler 2004; Previšic et al. 2009). Both C. fluminalis and $H$. contubernalis are examples of such species.

The investigated interglacial clay is a low-energy deposit that likely accumulated in a lake - probably near the mouth of a river as indicated by the two fluvial species.

\section{Other interglacial and interstadial deposits on Sjælland and Møn}

The new investigated site is located c. $500 \mathrm{~m}$ south of an overgrown coastal cliff with a layer of stones with an Eemian marine fauna that includes Paphia senescens (Madsen 1968). This last-mentioned deposit is located $10.5 \mathrm{~m}$ a.s.l., whereas the new interglacial deposit is located c. $35 \mathrm{~m}$ b.s.l., below a succession of clayey till and glaciofluvial gravel. Although located in the same area, these deposits appear to belong to two different interglacial stages.

Other marine faunas referred to the Eemian have been reported from Nebbegaard in NE Sjælland, the Former Free Port in Copenhagen, Strandegaards Dyrehave in SE Sjælland, Stubberup Have in eastern Møn and Hjelm Nakke in SE Møn as well as other sites on Møn (Fig. 4; Madsen et al. 1908; Ødum 1933; Petersen \& Konradi 1974; Berthelsen et al. 1977; Miller \& Mangerud 1985; Pedersen \& Gravesen 2021). Non-marine Eemian deposits have also been found on Møn (N. Hartz in Hinze 1937).

From Slettenshage on Røsnæs, NW Sjælland, a marine fauna dominated by the marine gastropod Turritella communis was described by Petersen (1973). Based on amino acid analyses, the occurrence was correlated with Holsteinian deposits in NW Germany 


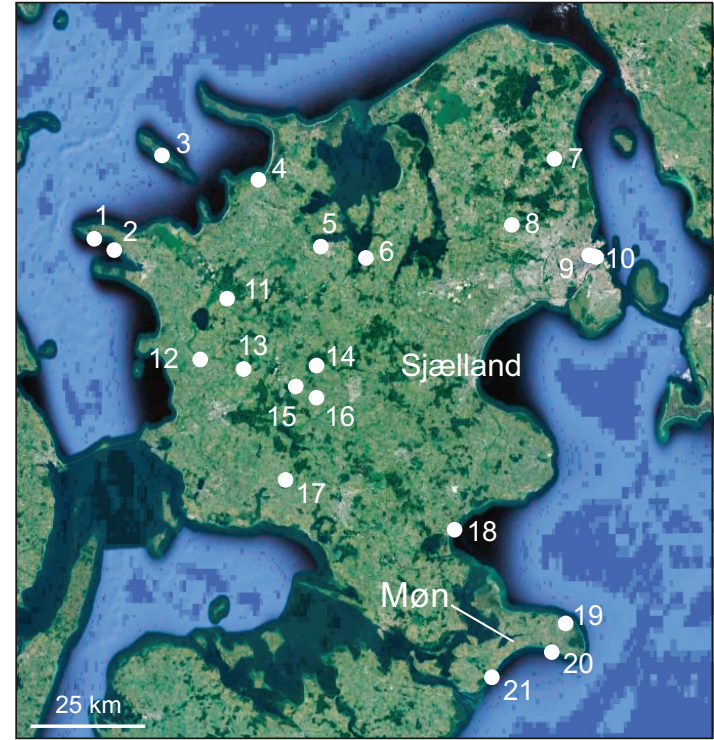

Fig. 4 Google Earth image of Sjælland and Møn showing localities mentioned in the text. 1: Slettenshage. 2: Skambæks Mølle. 3: Sejerø. 4: Høve. 5: Holbæk. 6: Ejby. 7: Nebbegaard. 8: Måløv. 9: Trianglen. 10: the former Free Port in Copenhagen. 11: Holmstrup. 12: Høng. 13: Nordrup. 14: Gyrstinge. 15: Bjernede. 16: Fjenneslev. 17: Førslevgaard. 18: Strandegaards Dyrehave. 19: Stubberup Have. 20: Kobbelgård/Klintholm. 21: Hjelm Nakke.

(Miller \& Mangerud 1985). Another interglacial deposit from Røsnæs, near Skambæks Mølle (Madsen et al. 1908), may be of the same age.

As mentioned earlier, interglacial non-marine deposits referred to MIS 7 are known from the former Free Port in Copenhagen and nearby Trianglen (Bennike et al. 2019; location in Fig. 1). Other Middle Pleistocene occurrences have been reported from Måløv (Bennike et al. 2011; location in Fig. 1) and Førslevgaard (Johansen 1904; Hartz 1909).

Interstadial Weichselian non-marine deposits have been reported from Kobbelgård and Klintholm, SE Møn (Bennike et al. 1994; Houmark-Nielsen et al. 2016) and Sejerø (Bennike et al. 2007). Marine interstadial deposits with boreoarctic or Arctic faunas have been reported from Høve (Milthers 1900; Ødum 1933), Holbæk, Høng (Ødum 1933), Nordruplund, Bjernede and Fjenneslev (Ødum 1933; Lykke-Andersen 1990), Gyrstinge (Sorgenfrei 1945) and Holmstrup (Petersen \& Buch 1974). Lists of macrofossils reported from the sites are shown in Table S1.

\section{Conclusions}

We conclude that the clayey deposit found at Ejby was deposited in a low-energy fluvial environment. The mean July temperature was likely higher than in Denmark today, and the deposit is clearly interglacial rather than interstadial. The occurrence of the bivalve
Corbicula fluminalis indicates that the deposit is probably of pre-Eemian, Middle Pleistocene age, at least 200000 years BP.

\section{Acknowledgements}

We thank the reviewers for their valuable corrections to the manuscript.

\section{Additional information}

Funding statement

This study did not receive any funding.

\section{Author contributions}

OB: macrofossil analyses, manuscript writing. PWL: identification and interpretation of Trichoptera remains as well as supplementary writing/ editing of the manuscript.

\section{Competing interests}

None declared.

\section{Additional files}

One additional file is available at $h$ ttps://doi.org/10.22008/FK2/QEUAXO

\section{References}

Andersen, S.T. 1967: Kvartærtiden. Istider og mellemistider i Danmark. In: Nørrevang, A. \& Meyer, T.J. (eds): Danmarks Natur 1, Landskabernes Opståen, 199-250. Copenhagen: Politikens Forlag.

Ashton, N., Lewis, S.G., Parfitt, S.A., Penkman, K.E.H. \& Coope, G.R. 2008: New evidence for complex climate change in MIS 11 from Hoxne, Suffolk, UK. Quaternary Science Reviews 27, 652-668. https://doi. org/10.1016/j.quascirev.2008.01.003

Bennike, O., Hedenäs, L., High, K., Korshøj, J.S., Lemdahl, G., Penkman, K., Preece, R.C., Rosenlund, K. \& Viehberg, F.A. 2019: New interglacial deposits from Copenhagen, Denmark: Marine Isotope Stage 7. Boreas 48, 107-118. https://doi.org/10.1111/bor.12342

Bennike, O., Houmark-Nielsen, M., Böcher, J. \& Heiberg, E.O. 1994: A multi-disciplinary macrofossil study of Middle Weichselian sediments at Kobbelgård, Møn, Denmark. Palaeogeography, Palaeoclimatology, Palaeoecology 111,1-15. https://doi.org/10.1016/0031-0182(94)90344-1

Bennike, O., Houmark-Nielsen, M. \& Wiberg-Larsen, P. 2007: A Middle Weichselian interstadial lake deposit on Sejerø, Denmark: macrofossil studies and dating. Journal of Quaternary Science 22, 647-651. https://doi.org/10.1002/jqs.1084

Bennike, O., Lindgård, E., Granat, H.J., Preece, R.C. \& Viehberg, F. 2011: A new Middle Pleistocene interglacial sequence from Måløv, Sjælland, Denmark. Geological Survey of Denmark and Greenland Bulletin 23, 29-32. https://doi.org/10.34194/geusb.v23.4805

Berthelsen, A., Konradi, P. \& Petersen, K.S. 1977: Kvartære lagfølger og strukturer i Vestmøns klinter. Dansk Geologisk Forenings Årsskrift for 1976, 93-99.

Candy, I., Tye, G., Coxon, P., Hardiman, M., Matthews, I. \& Palmer, A. 2021: A tephra-based correlation of marine and terrestrial records of MIS 11c from Britain and the North Atlantic. Journal of Quaternary Science 36, 1149-1161. https://doi.org/10.1002/jqs.3367

Coope, G.R. \& Böcher, J. 2000: Coleoptera from the Late Weichselian deposits at Nørre Lyngby, Denmark and their bearing on palaeoecology, biogeography and palaeoclimate. Boreas 29, 26-34. https://doi. org/10.1111/j.1502-3885.2000.tb01198.x

Hartz, N. 1909: Bidrag til Danmarks tertiære og diluviale flora. Danmarks Geologiske Undersøgelse II. Række 20, 292 pp. https://doi. org/10.34194/raekke2.v20.6804

Hintze, V. 1937: Møens Klints geologi, 410 pp. Copenhagen: Reitzels Forlag. Horton, A., Keen, D.H., Field, M.H., Robinson, J.E., Coope, G.R., Currant, A.P., Graham, D.K., Green, C.P. \& Phillips, L.M. 1992: The Hoxnian interglacial 
deposits at Woodston, Peterborough. Philosophical Transactions: Biological Sciences 338, 131-164. https://doi.org/10.1098/rstb.1992.0136 Houmark-Nielsen, M., Bennike, O., Lemdahl, G. \& Lüthgens, C. 2016: Evidence of ameliorated Middle Weichselian climate and environments in the western Baltic region: coring lake sediments at Klintholm, Møn, Denmark. Boreas 45, 347-359. https://doi.org/10.1111/bor.12159

Hungerer, K.B. \& Kadereit, J.W. 1998: The phylogeny and biogeography of Gentiana L. sect. Ciminalis (Adans.) Dumort.: a historical interpretation of distribution ranges in the European high mountains. Perspectives in Plant Ecology, Evolution and Systematics 1, 121-135. https:// doi.org/10.1078/1433-8319-00055

Johansen, A.C. 1904: Om den Fossile Kvartære Molluskfauna i Danmark og dens Relationer til Forandringer i Klimaet, 137 pp. Copenhagen: Gyldendalske Boghandel.

Kuneš, P., Kjærsgaard Sørensen, M., Buylaert, J.-P., Murray, A.S., Houmark-Nielsen, M. \& Odgaard, B.V. 2013: A new Middle Pleistocene interglacial record from Denmark: chronostratigraphic correlation, palaeovegetation and fire dynamics. Boreas 42, 596-612. https://doi. org/10.1111/bor.12002

Langford, H.E., Boreham, S., Briant, R.M., Coope, G.R., Horne, D.J., Schreve, D.C., Whittaker, J.E. \& Whitehouse, N.J. 2014: Middle to Late Pleistocene palaeoecological reconstructions and palaeotemperature estimates for cold/cool stage deposits at Whittlesey, eastern England. Quaternary International 341, 6-26. https://doi.org/10.1016/j.quaint.2014.01.037

Lykke-Andersen, A.-L. 1990: Marine aflejringer fra Sen Elster på Sjælland. Dansk Geologisk Forening, Årsskrift 1987-88, 77-80.

Madsen, E. 1968: En arkæologisk-geologisk undersøgelse af klinten ved Ejby Bro, Isefjord. Meddelelser fra Dansk Geologisk Forening 18, 33-45.

Madsen, V., Nordmann, V. \& Hartz, N. 1908: Eem-Zonerne. Studier over Cyprinaleret og andre Eem-Aflejringer i Danmark, Nord-Tyskland og Holland. Danmarks Geologiske Undersøgelse II. Række 17(1), 302 pp. https://doi.org/10.34194/raekke2.v17.6799

Meijer, T. \& Preece, R.C. 2000: A review of the occurrence of Corbicula in the Pleistocene of North-west Europe. Geologie en Mijnbouw/Netherlands Journal of Geosciences 79, 241-255. https://doi.org/10.1017/ s0016774600021739

Miller, G.H. \& Mangerud, J. 1985: Aminostratigraphy of European marine interglacial deposits. Quaternary Science Reviews 4, 215-278. https:// doi.org/10.1016/0277-3791(85)90002-2

Milthers, V. 1900: Tellina calcarea leret ved Høve i Odsherred. Meddelelser fra Dansk Geologisk Forening 1, 37-44.
Neu, P., Malicky, H., Graf, W. \& Schmidt-Kloiber, A. 2018: Distribution atlas of European trichopteran, 891 pp. Germany: ConchBooks, Harxheim.

Odgaard, B.V., Knudsen, K.L., Bennike, O. \& Granat, H.J. 2016: Middle Pleistocene interglacial deposits near Herning, Jylland, Denmark. Geological Survey of Denmark and Greenland Bulletin 35, 47-50. https://doi.org/10.34194/geusb.v35.4925

Pedersen, S.A.S. \& Gravesen, P. 2021: Kortbladsbeskrivelse, Geologisk kort over Danmark, 1:50 000, Møn, Dele af 1511 I, 1511 IV og 1512 II. GEUS Bulletin 48, 8293. https://doi.org/10.34194/geusb.v48.8293

Petersen, K.S. 1973: Tills in dislocated drift deposits on the Røsnæs peninsula, northwestern Sjælland, Denmark. Bulletin of the Geological Institute, University Uppsala 5, 41-49.

Petersen, K.S. \& Buch, A. 1974: Dislocated tills with Paleogene and Pleistocene marine beds: tectonics, lithology, macro- and microfossils. Danmarks Geologiske Undersøgelse Årbog 1973, 63-91.

Petersen, K.S. \& Konradi, P.B. 1974: Lithologisk og palæontologisk beskrivelse af profiler i Kvartæret på Sjælland. Dansk Geologisk Forening Årsskrift 1973, 47-56.

Previšic, A., Walton, C., Kucinic, M., Mitrikeski, P.T. \& Kerovec, M. 2009: Pleistocene divergence of Dinaric Drusus endemics (Trichoptera, Limnephilidae) in multiple microrefugia within the Balkan Peninsula. Molecular Ecology 18, 634-647. https://doi. org/10.1111/j.1365-294x.2008.04046.x

Ribera, I. \& Vogler, A.P. 2004: Speciation of Iberian diving beetles in Pleistocene refugia (Coleoptera, Dytiscidae). Molecular Ecology 13, 179-193. https://doi.org/10.1046/j.1365-294x.2003.02035.x

Rinne, A. \& Wiberg-Larsen, P. 2017: Trichoptera larvae of Finland. A key to the caddis larvae of Finland and nearby countries, $151 \mathrm{pp}$. Trificon.

Sorgenfrei, T. 1945: Mindre Meddelelser fra Danmarks Geologiske Undersøgelses Borearkiv, nr. 18. Marint Diluvium ved Gyrstinge. Meddelelser fra Dansk Geologisk Forening 10, 586-590.

Wiberg-Larsen, P. 2010: Oversigt over de danske vårfluer (Trichoptera) - og deres regionale udbredelse. Entomologiske Meddelelser 78, 3-20.

Wiberg-Larsen, P., Bennike, O., Jensen, J.B. \& Lemke, W. 2001: Trichoptera remains from early Holocene river deposits in the Great Belt, Denmark. Boreas 30, 299-306. https://doi.org/10.1111/j.1502-3885.2001. tb01049.x

Ødum, H. 1933: Marint Interglacial paa Sjælland, Hven, Møn og Rügen. Danmarks Geologiske Undersøgelse IV. Række 2(10), 44 pp. https:// doi.org/10.34194/raekke4.v2.6980 